\title{
RETROGRADE LABELING, ENRICHMENT, AND CHARACTERIZATION OF RETINAL GANGLION CELLS FROM THE NEONATAL RAT ${ }^{1}$
}

\author{
P. VIJAY SARTHY, ${ }^{2}$ BENSON M. CURTIS, AND WILLIAM A. CATTERALL* \\ Departments of Ophthalmology and *Pharmacology, University of Washington School of Medicine, Seattle, Washington 98195
}

Received April 7, 1983; Revised June 21, 1983; Accepted July 12, 1983

\begin{abstract}
We have developed a method for labeling retinal ganglion cells in neonatal rats by retrograde transport of the fluorescent dye, True Blue (TB), injected into the optic chiasm. Following proteolytic dissociation of labeled retinas into single cells, the labeled cells could be enriched 50- to 100 -fold by centrifugation in a 5\%/10\% metrizamide gradient. When plated in Ham's F-10 medium in the presence of fetal calf serum and chick optic tectum-conditioned medium, the labeled cells could be maintained in vitro up to $48 \mathrm{hr}$. In these cultures, the ganglion cells (GCS) constituted 50 to $70 \%$ of the total cell population. When GC-rich fractions or GC cultures were stained with a monoclonal antibody to Thy- 1 antigen, $>90 \%$ of the TB-labeled cells were reactive. In order to localize voltage-sensitive sodium channels, GC-rich cultures were reacted with ${ }^{125} \mathrm{I}$-scorpion toxin. Analysis of the autoradiograms showed that the density of silver grains was about 10 -fold higher on TB-labeled cells than on nonfluorescent cells, or in controls which contained excess of unlabeled toxin. When GC cultures were incubated with micromolar concentrations of putative GC transmitters, aspartate and glutamate, the amino acids were accumulated by 15 to $20 \%$ of labeled cells. Several lectin receptors were also localized on TB-labeled cells in situ. Whereas the lectins wheat germ agglutinin, concanavalin A, peanut agglutinin, Dolichos biflorus agglutinin, and Limulus polyphemus agglutinin bound to TB-labeled cells, others such as Ricinus communis agglutinin I, Ulex, and Lotus lectins showed no binding. The lectin binding was specific since preincubation with the appropriate hapten sugar blocked lectin binding.
\end{abstract}

Biochemical analysis of neurons is complicated by the presence of heterogeneous populations of neurons and non-neuronal cells in the nervous system (Peters et al., 1976). Primary neuronal cultures provide an opportunity to resolve this cellular heterogeneity (Varon and Saier, 1975). However, the analytical potential of the cell culture system is presently limited by two considerations. First, the identity of the different classes of neurons present in these cultures is often uncertain. Second, the enrichment or deprival for a particular cell type is usually unknown.

In this study, we describe a method for selective marking and enrichment of retinal ganglion cells from neo-

\footnotetext{
${ }^{1}$ This study was supported in part by National Institutes of Health Grants EY-01730 and EY-03664 to P. V. S., by Grant BNS 80-21619 from the National Science Foundation to W. A. C., and in part by an unrestricted grant from Research to Prevent Blindness, Inc. We thank Julie Seng for typing the manuscript and Jim Foltz and Brad Clifton for photographic help.

${ }^{2}$ To whom correspondence should be sent, at Department of Ophthalmology, RJ-10, University of Washington, Seattle, WA 98195.
}

natal rats. Ganglion cells were labeled by retrograde transport of the fluorescent dye, True Blue (TB), injected into the optic chiasm (Kuypers, 1981). Upon proteolytic dissociation of labeled retinas, individual ganglion cells were readily identified by the characteristic TB fluorescence. Centrifugation of the cell suspension in a metrizamide gradient leads to a 50 - to 100 -fold enrichment of labeled cells. The separated cells were viable and could be maintained in vitro for a few days. The localization of voltage-sensitive sodium channels, the Thy-1 antigen, lectin receptors, and neurotransmitter amino acid uptake systems associated with the labeled ganglion cells are presented here.

\section{Materials and Methods}

True Blue labeling. Pups from Sprague-Dawley rats (Tyler Laboratories, Bellevue, WA) were anesthetized by chilling on ice or by injecting pentobarbital, $0.5 \mathrm{mg}$, i.p., 8 to $12 \mathrm{hr}$ after birth. A pup from each litter was sacrificed to establish injection coordinates which were always centered on the junction of the frontal-parietal and sag- 
ittal sutures, but varied in depth from 4.5 to $5 \mathrm{~mm}$. The optic chiasms of the remaining pups were injected with $1 \mu \mathrm{l}$ of isotonic saline containing $10 \%(\mathrm{w} / \mathrm{v})$ of the fluorescent dye, True Blue (TB) (from Dr. K. G. Illing), and $1 \%$ lysolecithin. Four hours after the injections, pups were returned to their mother.

Two days after the injection, animals were anesthetized with ether and decapitated. After enucleation, retinas were dissected free. To localize labeled cells, retinas were fixed overnight with $4 \%$ paraformaldehyde in $0.1 \mathrm{M}$ sodium phosphate buffer, $\mathrm{pH}$ 7.4. After dehydration in an ethanol series, retinas were embedded in methacrylate for radial sectioning (Sarthy and Balkema, 1981). Fivemicrometer sections were cut on a JB-4 microtome, mounted in $95 \%$ glycerol, and examined for fluorescence using a Zeiss microscope equipped for epifluorescence (exciter filter G365, dichroic reflector 395, and barrier filter LP420).

Cell dissociation and plating. Retinas from injected pups were dissected free in Ham's F-10 medium containing $10 \%$ fetal calf serum (FCS). Retinas were transferred to $\mathrm{Ca}^{2+}$-, $\mathrm{Mg}^{2+}$-free medium and incubated for $5 \mathrm{~min}$ at $37^{\circ} \mathrm{C}$. After a further incubation with $0.25 \%$ trypsin in $\mathrm{Ca}^{2+}-\mathrm{Mg}^{2+}$-free medium for $20 \mathrm{~min}$, retinas were rinsed in Ham's F-10 medium containing FCS and dissociated by trituration through a siliconized Pasteur pipette. After counting in a hemocytometer, cells were seeded in F-10 (FCS) on polyornithine-coated plates at a density of $2 \times$ $10^{6}$ cells $/ \mathrm{cm}^{2}$.

Assay for ganglion cell survival. Ganglion cell survival in the presence of conditioned media and extracts was determined from fluorescent cell counts of cultures grown on polyornithine-coated $35-\mathrm{mm}$ dishes (Falcon) or on 14-mm Aclar discs (Allied Chemical, Fabricated Products Division, Morristown, $\mathrm{NJ}$ ) in 24-chamber multiwell plates (Costar, Cambridge, MA).

At required intervals, discs were washed with phosphate-buffered saline $(0.9 \% \mathrm{NaCl}$ in $0.01 \mathrm{M}$ phosphate buffer, $\mathrm{pH} 7.4$ ) and fixed overnight in $4 \%$ paraformaldehyde. After a wash in distilled water, the discs were coverslipped in $50 \%$ glycerol and examined for fluorescence at $\times 400$ magnification. The number of TB-labeled cells per disc was determined from counts in a $250-\mu \mathrm{m}$ strip across the width of the disc. Four strips were counted per disc. Each experiment tested the effect of additives on ganglion cells from two retinas. Within an experiment each sample was assayed in duplicate except for controls, which were in triplicate. Conditioned medium was assayed as a $1: 1(\mathrm{v} / \mathrm{v})$ dilution with Ham's F10 (FCS). Serum-free conditioned medium and brain extracts were mixed 1:1 with a 2-fold concentration of Ham's F-10 (FCS) before assay. In either case, the total volume of media and additives was $0.6 \mathrm{ml} /$ well to which was added $0.2 \mathrm{ml}$ of retinal cells containing approximately 15,000 labeled ganglion cells.

Metrizamide gradients. Cell suspensions in Ham's F10 medium at $4^{\circ} \mathrm{C}$ were mixed with $30 \%(\mathrm{w} / \mathrm{v})$ metrizamide (Accurate Chemical and Scientific Co., Westbury, $\mathrm{NY}$ ) in Ham's F-10 medium to give a final concentration of $10 \%$ metrizamide. This mixture was transferred to a chilled, sterile centrifuge tube and a step gradient was formed by overlaying 5\% metrizamide in Ham's F-10 medium. The gradient was centrifuged at $3000 \times \mathrm{g}$ for $25 \mathrm{~min}$ at $4^{\circ} \mathrm{C}$ in a Sorvall HB-24 rotor. The 5 to $10 \%$ interface was recovered and diluted 10 -fold with cold Ham's F-10 medium. Cells were pelleted by centrifugation at $60 \times g$ for $10 \mathrm{~min}$ and then resuspended in Ham's F-10 (FCS). Cells were seeded at a density of $8 \times 10^{5} /$ $\mathrm{cm}^{2}$ on polyornithine plates precoated with chick optic tectum conditioned medium.

Scorpion toxin binding. Ganglion cell cultures grown in Lab-tek tissue culture slides (VWR Scientific, Seattle, WA) were rinsed and preincubated in $\mathrm{Na}^{+}$-free medium containing $5 \%$ bovine serum albumin (BSA) and $1 \mu \mathrm{M}$ tetrodotoxin (Catterall, 1981). After $5 \mathrm{~min}$ at room temperature $\left(22 \pm 2^{\circ} \mathrm{C}\right)$; the medium was replaced by $0.5 \mathrm{ml}$ of $\mathrm{Na}^{+}$-free medium containing $1 \mathrm{nM}^{125}$ I-labeled scorpion toxin (Leiurus quinquestriatus toxin), 5\% BSA, and 1 $\mu \mathrm{M}$ tetrodotoxin. In the controls, $150 \mathrm{nM}$ unlabeled toxin was present. After $1 \mathrm{hr}$ of incubation at room temperature, the incubation medium was removed and the cells were washed once with sodium phosphate buffer $(0.1 \mathrm{M}$, $\mathrm{pH}$ 7.4) containing $1 \%$ BSA. Following five 2 -min washes in cold phosphate buffer without BSA, the cells were fixed in $4 \%$ fresh paraformaldehyde overnight in a refrigerator. Next, the slides were rinsed with distilled water, air-dried, and processed for autoradiography (Sarthy, 1982).

Thy-1 localization. For localization of the Thy-1 antigen on isolated cells, $0.5 \mathrm{ml}$ of the ganglion cell-enriched fraction from metrizamide gradient was fixed in $4 \%$ paraformaldehyde for $1 \mathrm{hr}$ at $4^{\circ} \mathrm{C}$. After centrifugation and washing to get rid of excess aldehyde, the cells were reacted with 1:100 dilution of a mouse monoclonal antibody to Thy-1 antigen (New England Nuclear, Boston, MA). After $4 \mathrm{hr}$ at $0^{\circ} \mathrm{C}$, the cells were pelleted and washed three times in phosphate buffer. The cells were resuspended and incubated with rhodamine $(\mathrm{Rh})$-conjugated anti-mouse rabbit antibody (N. L. Cappel Laboratories, Cochranville, PA) for $1 \mathrm{hr}$ at $4^{\circ} \mathrm{C}$. After three washes, the cells were mounted in glycerol containing $n$-propyl gallate (Giloh and Sedat, 1982) and examined for fluorescence. The antibody was bound to ganglion cell cultures by the same procedure except that incubation with the primary antibody was carried out overnight. The controls in both experiments did not contain the Thy-1 antibody. Controls were also carried out with supernatant of the myeloma line N-S.8.1.

${ }^{3} \mathrm{H}$-Amino acid uptake. Ganglion cell cultures grown in Lab-tek slides were rinsed and incubated in mammalian bicarbonate Ringer (MBR) containing $0.5 \mu \mathrm{M} \mathrm{D}-\left[{ }^{3} \mathrm{H}\right]$ aspartate $(20 \mathrm{Ci} / \mathrm{mmol})$ or $\left[{ }^{3} \mathrm{H}\right]$ glutamate $(44.1 \mathrm{Ci} / \mathrm{mmol})$ for $10 \mathrm{~min}$ at $37^{\circ} \mathrm{C}$. After three washes in MBR, the cells were fixed overnight in $1 \%$ paraformaldehyde. After washing, the slides were air-dried and processed for autoradiography. The controls were supplemented with $100 \mu \mathrm{M} \mathrm{D}$-aspartate or glutamate as required.

Lectin binding. Cultures grown in $35-\mathrm{mm}$ plates were rinsed in MBR and incubated with $1 \mathrm{ml}$ of an Rhconjugated lectin solution (50 to $100 \mu \mathrm{g} / \mathrm{ml}$ ) for $30 \mu \mathrm{min}$ at $22^{\circ} \mathrm{C}$ with gentle agitation. The cultures were rinsed several times with MBR to get rid of excess lectin, and examined under a Zeiss inverted microscope fitted for $\mathrm{Rh}$ and TB fluorescence. In order to examine the speci- 
ficity of lectin binding, lectins were preincubated with $100 \mathrm{~mm}$ hapten sugar for $30 \mathrm{~min}$ at room temperature before adding to the cultures. The sugars used were: methyl- $\alpha$-D-mannoside for concanavalin $\mathrm{A} ; N$-acetylglucosamine for wheat germ agglutinin; D-galactose for peanut agglutinin; $N$-acetylgalactosamine for Dolichos biflorus agglutinin; and sialic acid for Limulus polyphemus agglutinin (Sarthy et al., 1981).

Media. Ham's F-10 medium (Grand Island Biological Co., Grand Island, NY) was supplemented with $28 \mathrm{mM}$ glucose, $14 \mathrm{~mm} \mathrm{NaHCO}_{3}, 1 \mathrm{mg} / \mathrm{ml}$ of kanamycin, and $0.5 \mathrm{mg} / \mathrm{ml}$ of gentamycin. When required, $10 \%(\mathrm{v} / \mathrm{v})$ heat-inactivated fetal bovine serum (K. C. Biologicals, Lenexa, KS) was added. For coating plates, $0.1 \mathrm{mg} / \mathrm{ml}$ of polyornithine (ICN Pharmaceuticals, Inc., Cleveland, $\mathrm{OH}$ ) in water was left covering the dish surface for $24 \mathrm{hr}$ at room temperature and was washed twice with water before adding media. Tissue extract or conditioned medium (CM) was bound to culture surface by incubating polyornithine-coated plates overnight at $37^{\circ} \mathrm{C}$; the unbound material was aspirated off and plates were rinsed two times before adding culture media. The media and extracts were prepared as described by Nurcombe and Bennett (1981).

All chemicals were reagent grade and were usually obtained from Sigma Chemical Co. (St. Louis, MO). Rhodamine-conjugated lectins were supplied by $\mathrm{E}$. Y. Laboratories, Inc. (San Mateo, CA). ${ }^{3} \mathrm{H}$-Amino acids and anti-Thy-1 monoclonal antibody were purchased from New England Nuclear Corp. (Boston, MA). ${ }^{125}$ I-labeled scorpion toxin was prepared as described elsewhere (Catterall, 1977).

\section{Results}

Crucial to the validity of this study is the demonstration that TB injections into the optic chiasm labeled retinal ganglion cells alone. Figure $1 B$ presents a fluorescence micrograph of a TB-labeled retina 2 weeks after dye injection. It is evident that even after such a long survival time, all labeled cells are confined to the ganglion cell layer. Furthermore, no "halos" were found around the labeled cell bodies in whole mounts of the retina (data not shown). Also, there was no significant decrease in cell density compared to control sections.

After $24 \mathrm{hr}$ survival time, few fluorescent cells were seen among the dissociated cells. However, after $48 \mathrm{hr}$, 0.5 to $1 \%$ of the cells were labeled with either uniform or speckled blue fluorescence characteristic of TB (Potts et al., 1982). These fluorescent cells were the largest in size $(10$ to $15 \mu \mathrm{m})$ (Fig. $1, C$ and $D$ ).

Six hours after seeding, most of the labeled ganglion cells had attached to the dish; in many cases, they had also sent out a few neurites. In these cultures, the ganglion cells had the largest somata and a "flattened" appearance compared to nonlabeled cells (Fig. 2, $A$ and $B)$. At $24 \mathrm{hr}$, although some "flattened" cells were still seen, the majority of ganglion cells had rounded up and displayed a smaller soma. Furthermore, some of the TBlabeled cell bodies had extended processes (Fig. 2, $C$ and $D$ ). After $48 \mathrm{hr}$ many TB-fluorescent cells had a dis- rupted membrane and poor morphology (Fig. 2, $E$ and $F)$. Examination of media at $48 \mathrm{hr}$ with trypan blue revealed a preponderance of dead cells with large soma.

Counts of labeled and unlabeled cells revealed that, although the total number of cells remained unchanged, the number of ganglion cells on the plates decreased drastically, reducing to $80 \%$ of initial density by $48 \mathrm{hr}$. Chick optic tectum CM and rat superior colliculus extracts maintained the number of ganglion cells up to 24 hr. Subsequently, however, the ganglion cell number decreased to about $25 \%$ of the initial value by $48 \mathrm{hr}$. Additives derived from non-target areas such as rat cerebellum did not produce an effect on ganglion cell number significantly different from that of control. Similar observations have heen reported by McCaffrey et al. (1982). In subsequent experiments, we used polyornithine plates precoated with chick optic tectum CM. The plating media were also supplemented with the same CM.

Enrichment. Although we were able to identify TBlabeled ganglion cells and maintain them in vitro for at least a 48-hr period, the labeled cells comprised a minor fraction of only 0.5 to $1 \%$ of the total number of cells in culture. For biochemical studies as well as for screening for putative trophic factors, we wanted a more enriched preparation of labeled cells.

Qualitative separation of dissociated neurons of different size classes has been achieved by centrifugation in metrizamide gradients (Schaffer et al., 1980; Sheffield et al., 1980; Schnaar and Schaffer, 1981). Since many of the ganglion cell bodies are the largest in size among the different cells in the retina (Fukuda, 1977), we examined fractionation of labeled cells on metrizamide gradients of various densities. We found that a two-layer $5 \% / 10 \%$ gradient was quite efficient in enriching for the TBlabeled cells.

The cells collected at the $5 \% / 10 \%$ metrizamide interface contained about 50 to $70 \%$ fluorescent cells (Fig. 3, $A$ and $B$ ). This procedure provided about a 100 -fold enrichment of ganglion cells as compared to the 0.5 to $1 \%$ fluorescent cells in retinal dissociates before enrichment. After $24 \mathrm{hr}$ in culture, ganglion cells could be identified in silu, without removing the medium, by their solid or specked blue fluorescence. These cells were phase bright, and many of them also had extended processes (Fig. 3, $C$ and $F$ ). As with the nonenriched preparations, only 20 to $25 \%$ of fluorescent cells were left attached to the plate after $48 \mathrm{hr}$ in vitro.

$\mathrm{Na}^{+}$channel localization. In the mammalian retina, tetrodotoxin-inhibited spike activity has been reported only from ganglion cells (Miller, 1979). Since such activity is associated with the presence of voltage-sensitive sodium channels in the membrane, we examined the binding of scorpion toxin to TB-labeled cells maintained in vitro (Catterall, 1977). The purified $\alpha$-toxin from the scorpion, Leiurus quinquestriatus, is a small, basic polypeptide which binds with a $K_{D}$ of $\sim 1 \mathrm{nM}$ to brain synaptosomes, to neuroblastoma cells, and to spinal cord neurons in vitro. In all of these systems, toxin binding is sensitive to voltage changes and is reduced by depolarization (Catterall, 1980, 1981). Furthermore, it is possible to prepare ${ }^{125}$ I-labeled toxin of high specific activity 
without changing its binding properties or the biological effect (Catterall, 1977).

Ganglion cell cultures of TB-labeled retinas were incubated with $1 \mathrm{nM}{ }^{125}$ I-labeled scorpion toxin in sodiumfree, choline-substituted incubation medium to prevent cell depolarization. Controls contained about $150 \mathrm{nM}$ unlabeled toxin in addition to the labeled toxin. After 1 $\mathrm{hr}$ of incubation at room temperature, the cells were washed repeatedly to remove excess toxin, fixed in $4 \%$ paraformaldehyde, and processed for autoradiography. Results of the experiment are presented in Figure 4, $A$ to $H$. In cultures treated with ${ }^{125} \mathrm{I}$-toxin alone, a large number of cells with an increased density of silver grains were readily observed (Fig. $4, A$ to $F$ ). In contrast, cells incubated with excess unlabeled toxin showed little enhancement in silver grain density (Fig. $4, G$ and $H$ ). When silver grain distribution and TB fluorescence of individual cells were examined, about $90 \%$ of the flu-
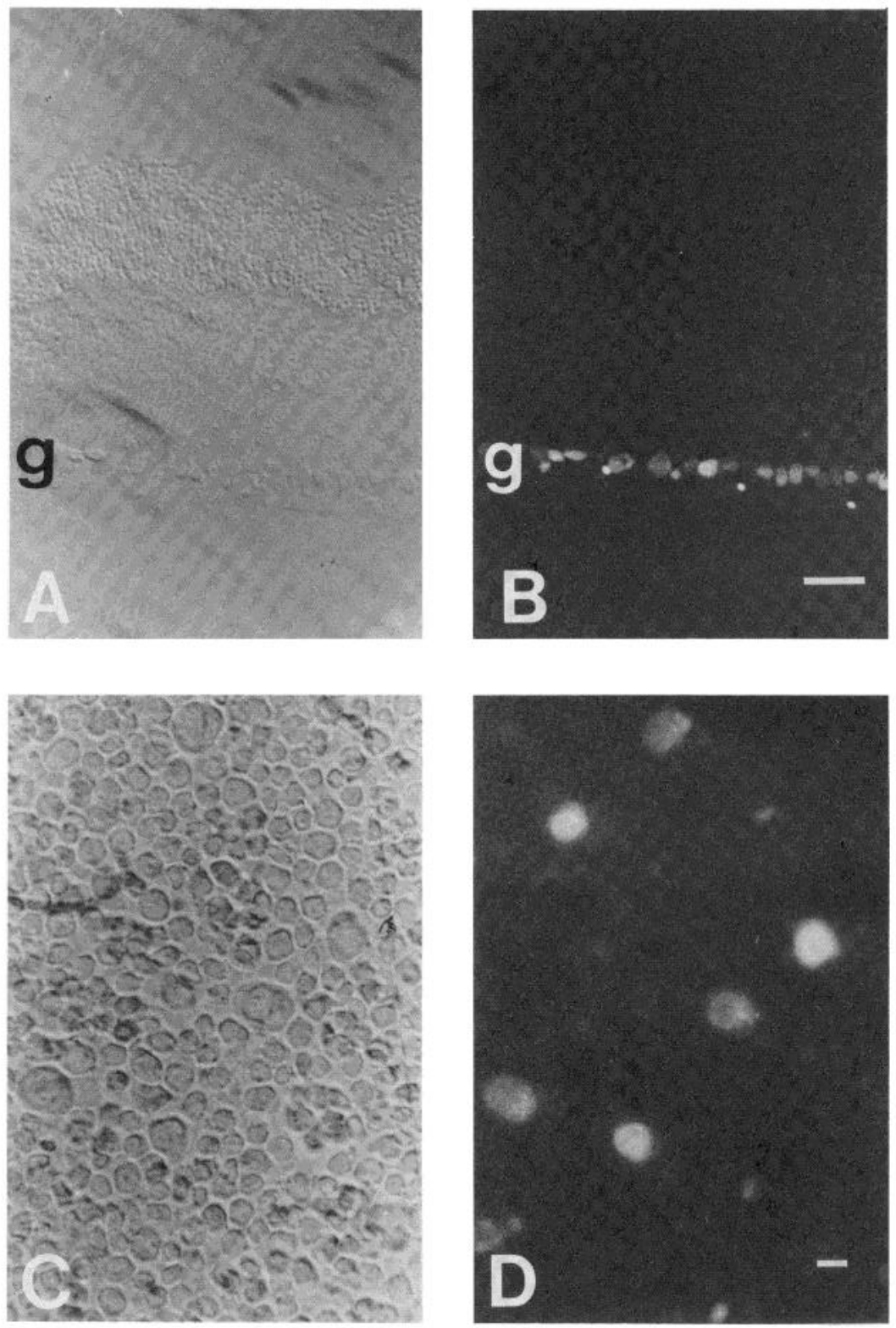

Figure 1. Localization of TB-labeled cells in retina and in dissociated cells. Newborn rat pups were injected with $1 \mu \mathrm{l}$ of $10 \%$ TB solution at the optic chiasm. After 2 weeks' survival, retinas were dissected out, fixed in $4 \%$ paraformaldehyde, and processed for fluorescence microscopy. Alternatively, labeled retinas were dissociated by trypsinization. Transverse sections of retina were viewed with Hoffmann modulation optics $(A)$ and epifluorescence $(B)$. The fluorescent cell bodies are localized to the ganglion cell layer. A pellet of cells obtained from dissociated retina was examined with Hoffmann optics $(C)$ and epifluorescence $(D)$. Note that the larger somata are labeled either uniformly or with speckled fluorescence. $g$, ganglion cell layer. Scale bar $=10 \mu \mathrm{m}$. 

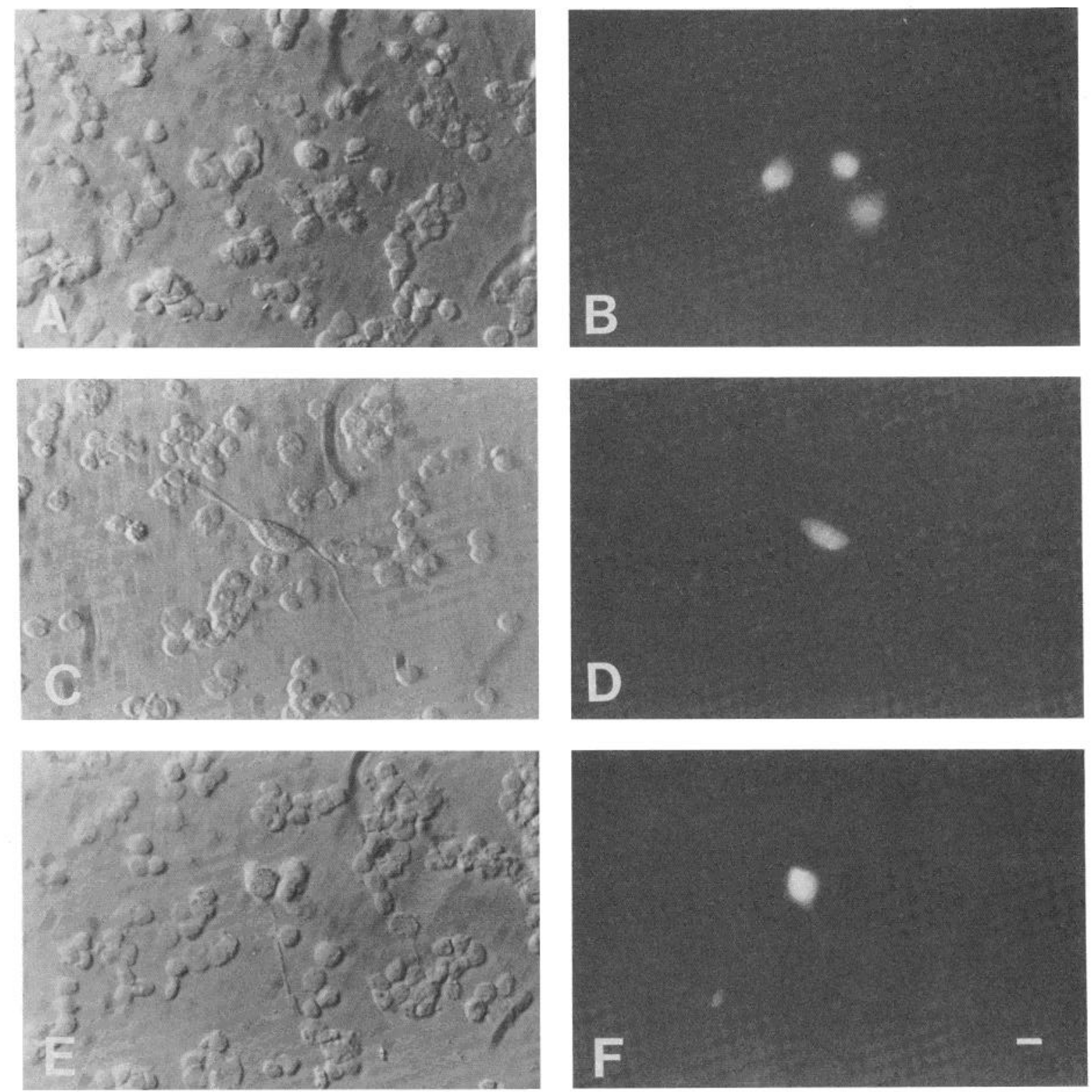

Figure 2. Identification of TB-labeled cells after plating. Dissociated single cells from TB-labeled retinas were plated on polyornithine dishes precoated with chick optic tectum conditioned medium as described under "Materials and Methods." Cultures were fixed with $4 \%$ paraformaldehyde and observed with Hoffmann optics $(A, C$, and $E)$ or epifluorescence $(B, D$, and $F)$ at time periods of $6 \mathrm{hr}(A$ and $B), 24 \mathrm{hr}(C$ and $D)$, and $48 \mathrm{hr}(E$ and $F)$. Scale bar $=10 \mu \mathrm{m}$.

orescent cells had an enhanced concentration of silver grains around them, whereas nonfluorescent cells showed grains at background levels (Fig. $4 B$ ). The distribution of silver grains was only slightly higher on fluorescent cells compared to nonfluorescent cells in controls. Since the number of silver grain on TB-labeled cells was somewhat variable, we decided to quantitate the grain density (Fig. $4, A$ to $F$ ).

In order to quantitate grain distribution, we determined the total number of silver grains around each cell. The fluorescence of that cell was also recorded subsequently. The density of silver grains was calculated by assuming that the grains were distributed over a hemisphere with a surface area of $1 / 2 \pi d^{2}$ where $d$, the diameter of the cell, was $12 \mu \mathrm{m}$ for fluorescent cells and $8 \mu \mathrm{m}$ for nonfluorescent cells. Table I presents the density of silver grains present on both fluorescent and nonfluorescent cells from experimental and control cultures. It is evident from the data that the silver grains are selectively associated with fluorescent cells. We infer that among the different cells in our retinal cultures, the TB-labeled cells, which are presumably ganglion cells, alone carry voltage-sensitive sodium channels on their surface.

Thy-1 localization. The Thy-1 antigen, a glycoprotein common to brain and thymus-derived lymphocytes (Williams et al., 1976), has been recently localized to the surface of ganglion cells in rat and mouse retinas (Beale and Osborne, 1982; C. Barnstable, personal communication). Following this observation, we have examined the presence of Thy-1 antigen on TB-labeled cells im- 

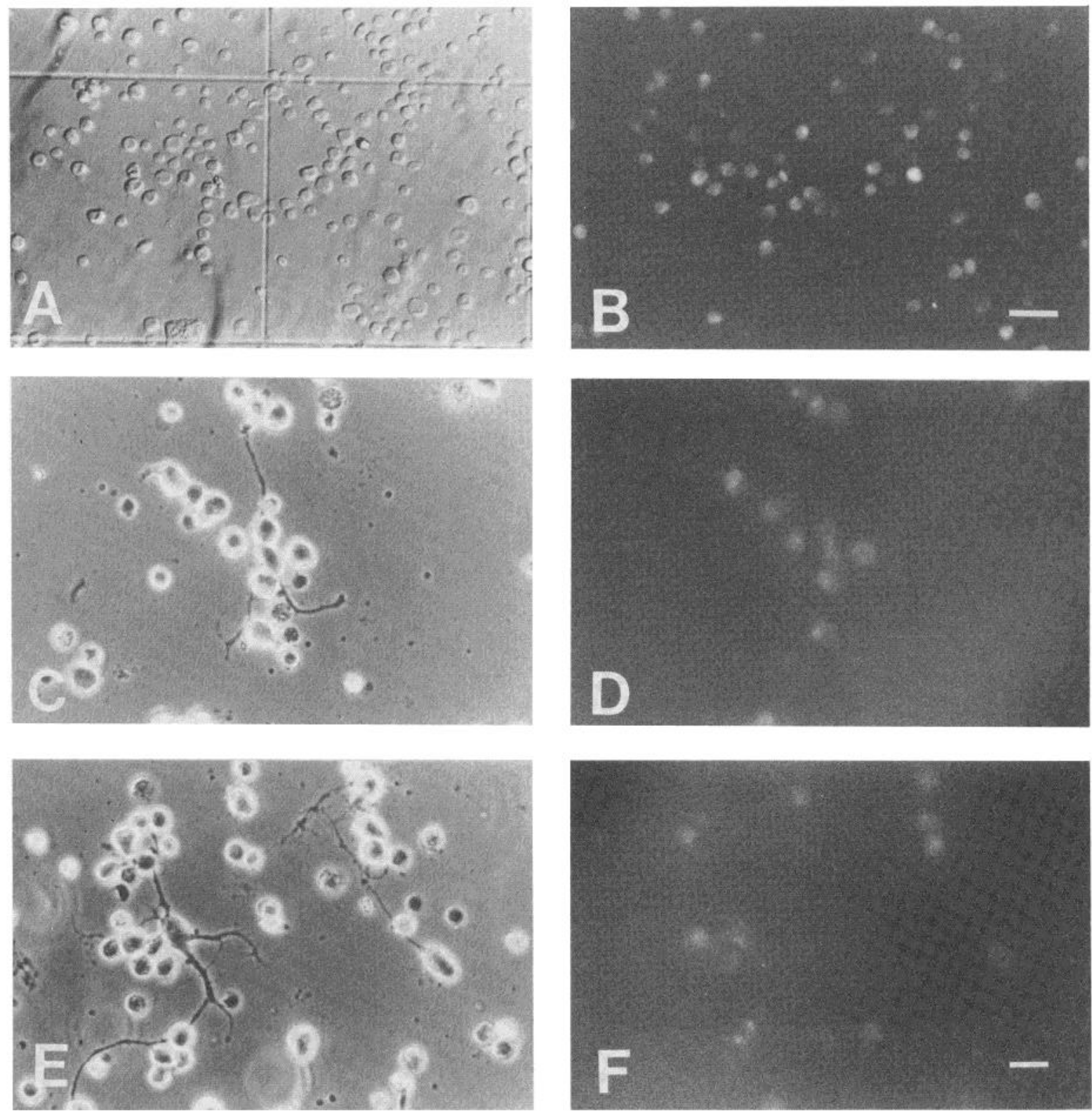

Figure 3. Enrichment of ganglion cells by density gradient centrifugation. Dissociated cells from TB-labeled retinas were centrifuged in a 5\%/10\% metrizamide gradient in Ham's F-10 medium, for $30 \mathrm{~min}$ at 4500 rpm in a Sorvall HB-24 rotor. Cells from the interface were collected, diluted 5 -fold, and pelleted by centrifugation. The pellet was resuspended and plated as described under "Materials and Methods." The ganglion cell-rich fraction from the interface was examined with Hoffmann optics $(A)$ and epifluorescence $(B)$. Note that $\sim 60 \%$ of the cells in $A$ have TB fluorescence $(B)$. Cultures of ganglion cell-rich fraction were observed in situ, $36 \mathrm{hr}$ after plating, with phase contrast optics $(C$ and $E)$ and epifluorescence $(D$ and $F)$. As with enriched cell fractions, the predominant class of cells in culture was fluorescent, Scale bar $=10 \mu \mathrm{m}$.

mediately after their isolation or after maintenance in vitro for $48 \mathrm{hr}$.

Ganglion cell suspensions or cultures were fixed with $4 \%$ paraformaldehyde and then reacted with anti-Thy-1 monoclonal antibody. Subsequently, the cells were labeled with $\mathrm{Rh}$-conjugated anti-mouse rabbit antibody, and the individual cells were examined for both TB and $\mathrm{Rh}$ fluorescence successively. Results of these experiments are presented in Figure $5, A$ to $F$. In dissociated cell suspensions, about $50 \%$ of the cells showed $\mathrm{Rh}$ fluorescence. On these cells, fluorescence was nonuniform and patchy. Furthermore, its intensity varied a great deal among the cells examined (Fig. 5, $A$ and $B$ ). The cultured cells, on the other hand, showed a more uniform but weaker surface fluorescence (Fig. 5, $C$ and $D$ ). In order to correlate Thy-1 antigen localization with TB fluorescence, 100 cells were initially identified by their TB fluorescence and later examined for their $\mathrm{Rh}$ fluorescence. In two separate experiments, $94 \%$ of the TB-positive cells showed Rh fluorescence. When 100 Rh-labeled cells were subsequently examined for TB fluorescence, $92 \%$ of the cells were TB positive. These data establish the presence of Thy-1 antigen on TBlabeled cells. 

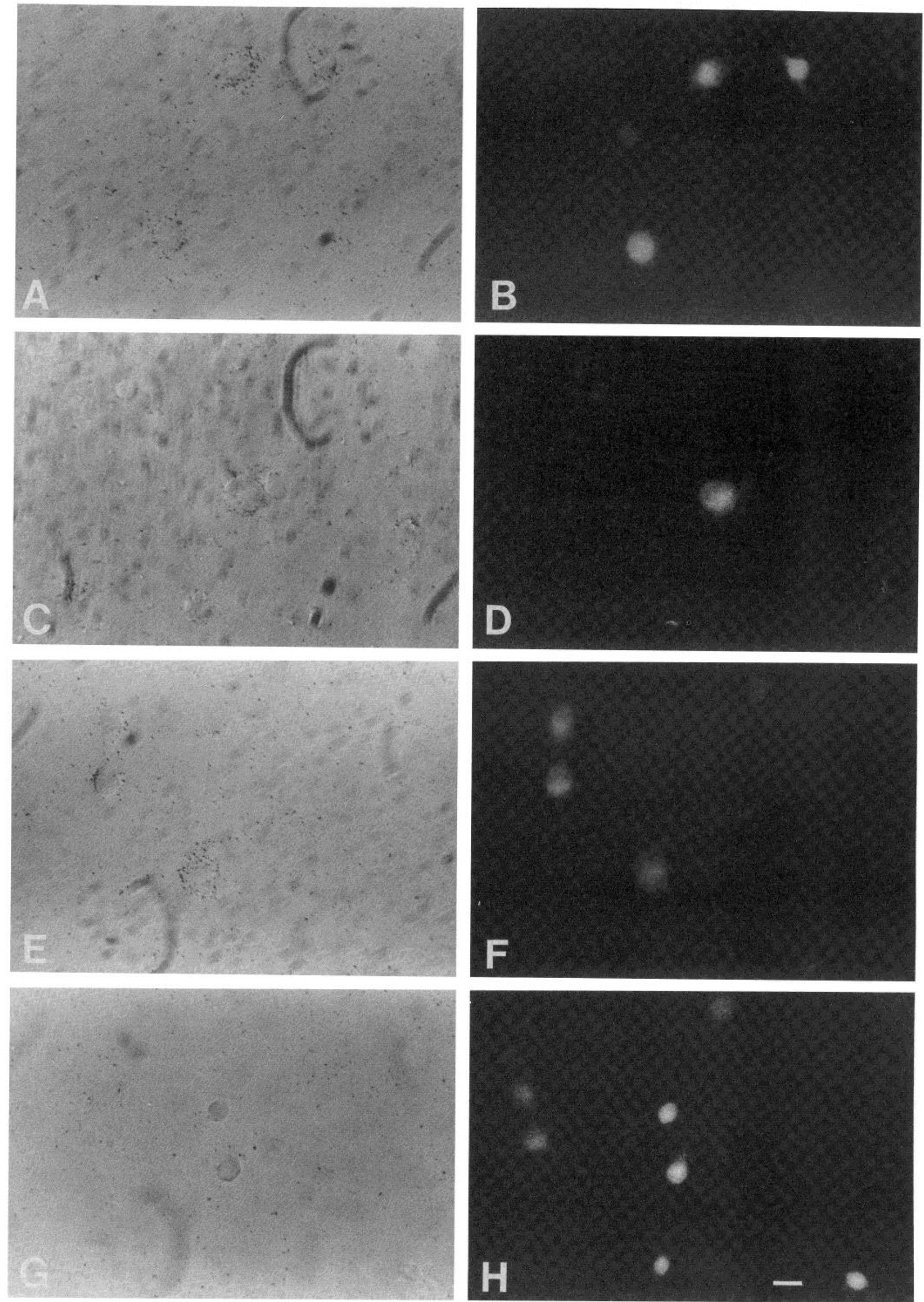
TABLE I

Distribution of sodium channels in ganglion cell cultures

The density of silver grains was calculated as the number of silver grains per 226 per $\mu \mathrm{m}^{2}$ for TB-labeled fluorescence and 100.5 per $\mu \mathrm{m}^{2}$ for nonfluorescent cells.

\begin{tabular}{llrc}
\hline & & $\begin{array}{c}\text { Number of Silver } \\
\text { Grains }\end{array}$ & $\begin{array}{c}\text { Density of Silver } \\
\text { Grains } / \mu \mathrm{m}^{2}\end{array}$ \\
\hline Experimental & Fluorescent & $27.5 \pm 4.5$ & $0.122 \pm 0.019$ \\
& Nonfluorescent & $1.8 \pm 1.1$ & $0.018 \pm 0.011$ \\
Control & Fluorescent & $3.7 \pm 2.2$ & $0.016 \pm 0.009$ \\
& Nonfluorescent & $2.1 \pm 1.0$ & $0.021 \pm 0.010$ \\
\hline
\end{tabular}

The ganglion cell cultures gave a slightly different result. When cells were located by TB fluorescence and subsequently examined for $\mathrm{Rh}$ fluorescence, virtually all cells were Rh positive. On the other hand, if cells were first located by $\mathrm{Rh}$ fluorescence and then examined for TB fluorescence, only about $80 \%$ of the cells were TB positive. Rh-labeled cells were about 50 to $60 \%$ of the total number of cells in these cultures. In both studies, the controls which were not exposed to anti-Thy-1 antibody showed only TB fluorescence (Fig. 5, $E$ and $F$ ). Furthermore, cultured cells incubated with supernatant of the BALB/c mouse myeloma line N-S.8.1 were also $\mathrm{Rh}$ negative (data not presented). These studies show that the Thy- 1 antigen is present on $>80 \%$ of the ganglion cells and thus can serve as a useful surface marker for rat retinal ganglion cells.

The $\mathrm{Na}^{+}$channel and Thy-1 localization studies establish that the TB-labeled cells are indeed ganglion cells. In order to further characterize the ganglion cell-rich preparations, we have examined the uptake of two putative ganglion cell transmitter candidates, aspartate and glutamate, and the binding of several Rh-labeled lectins to TB-labeled cells. The uptake studies were aimed at developing a protocol for light microscopic autoradiographic localization of transmitters and investigating the uptake of $\left[{ }^{3} \mathrm{H}\right]$ aspartate and $\left[{ }^{3} \mathrm{H}\right]$ glutamate. The objective of the lectin-binding studies was to explore the feasibility of localizing receptors on TB-labeled cells in situ by noninvasive techniques.

Amino acid uptake. Among the different retinal neurotransmitters, glutamate and aspartate have been suggested as putative transmitter candidates for a small population of ganglion cells in the vertebrate retina (Berger et al., 1977; Fonnum and Henke, 1979; Beaudet et al., 1981; Cuenod et al., 1981; Ehinger, 1981; Voaden et al., 1981; Wolfensberger et al., 1981). Since transmitter uptake is a useful criterion for identifying transmitter function, we examined the uptake of $\left[{ }^{3} \mathrm{H}\right]$ aspartate and $\left[{ }^{3} \mathrm{H}\right]$ glutamate by TB-labeled cells. When ganglion cell cultures were incubated with $D-\left[{ }^{3} \mathrm{H}\right]$ aspartate or $\left[{ }^{3} \mathrm{H}\right]$ glutamate $\left(\sim 0.5 \mu \mathrm{M}\right.$ each) for $10 \mathrm{~min}$ at $37^{\circ} \mathrm{C}$ and processed for autoradiography, only a small fraction of ganglion cells were labeled (Fig. $6, A$ and $C$ ). In three separate experiments, the fraction of labeled cells was between 15 and $20 \%$ of all fluorescent cells. When $\left[{ }^{3} \mathrm{H}\right]$ aspartate and $\left[{ }^{3} \mathrm{H}\right]$ glutamate were both present in incubation medium, about $20 \%$ of the cells were again labeled. Many nonfluorescent cells were also labeled with these amino acids, and we have not estimated their number. The uptake of $\left[{ }^{3} \mathrm{H}\right]$ aspartate and $\left[{ }^{3} \mathrm{H}\right]$ glutamate was blocked in the presence of $0.1 \mathrm{mM}$ concentration of the unlabeled amino acids (Fig. 6, $E$ and $F$ ).

Lectin receptors. Lectins are polypeptides which bind to specific sugars with high affinity and interact with oligosaccharides on cell surfaces (Lis and Sharon, 1973; Nicolson, 1976). These compounds have, therefore, been used as probes to investigate the nature of complex carbohydrates in numerous systems (see Nicolson, 1976; Oppenheimer, 1979). We have examined the binding of several lectins with particular interest in the feasibility of localizing these receptors on ganglion cells in situ by noninvasive techniques.

Cultures of TB-labeled retinas were washed in serumfree Ringer medium and incubated with Rh-labeled lectins for $30 \mathrm{~min}$ at room temperature $\left(\sim 22^{\circ} \mathrm{C}\right)$. Subsequently, the cultures were washed several times to get rid of excess lectin, and the cells were examined for both $\mathrm{Rh}$ and TB fluorescence. In control experiments, lectins were preincubated with the competing sugar before reacting with cells. Results of binding experiments with the lectin, wheat germ agglutinin (WGA), are presented in Figure 7, $A$ to $F$. In WGA-treated cultures, there was intense $\mathrm{Rh}$ fluorescence on both TB-labeled and TBnonlabeled cells. Furthermore, both processes and cell bodies were fluorescent (Fig. 7, $A$ to $C$ ). In the presence of $\mathrm{N}$-acetylglucosamine, a specific inhibitor of WGA binding, most of the fluorescence was suppressed (Fig. 7, $D$ to $F$ ).

Results obtained with several other lectins are given in Table II. It was found that the pattern and intensity of labeling varied with the lectin tested. WGA, concanavalin A, peanut agglutinin, Dolichos biflorus agglutinin, and Limulus polyphemus agglutinin all showed detectable binding above control levels for TB-positive cells, whereas Soybean agglutinin, Ricinus communis agglutinin I, Ulex, and Lotus lectins did not stain them. These results suggest that it is possible to localize lectin receptors and to establish the carbohydrate distribution on TB-labeled cells in situ.

\section{Discussion}

The validity of our study is based on the assumption that, among the different cell types present in the ganglion cell layer, the ganglion cell bodies alone are labeled with TB. Although retrograde transport can be expected to label ganglion cells selectively, subsequent dye leakage might lead to labeling of the adjoining displaced amacrine and glial cells. With certain dyes such as $4^{\prime}, 6$-diamidino-

Figure 4. Localization of ${ }^{125} \mathrm{I}$-scorpion toxin-binding sites on ganglion cells in culture. Forty-eight-hour-old ganglion cell-rich cultures were reacted with ${ }^{125}$ I-scorpion toxin and processed for autoradiography as described under "Materials and Methods." Light $(A, C$, and $E)$ and corresponding fluorescence $(B, D$, and $F)$ micrographs show that silver grains are preferentially associated with fluorescent cells. Occasionally $(<10 \%)$, TB-labeled cells with few silver grains around them were observed. In control experiments, $150 \mu \mathrm{M}$ unlabeled toxin was included in addition to the labeled toxin. Light $(G)$ and fluorescence $(H)$ micrographs of the control are shown. Scale bar $=10 \mu \mathrm{m}$. 
2-phenylindol-dihydrochloride (DAPI), bisbenzimide, and Nuclear Yellow, secondary labeling of neighboring cells leads to a "halo" around brightly labeled cells (Masland and Dräger, 1980; Kuypers, 1981). In our studies with TB, however, we did not observe any halos around labeled cells even 2 weeks after TB injection, suggesting that little dye leakage occurred from labeled cells. Secondary labeling might also take place if cells are con-
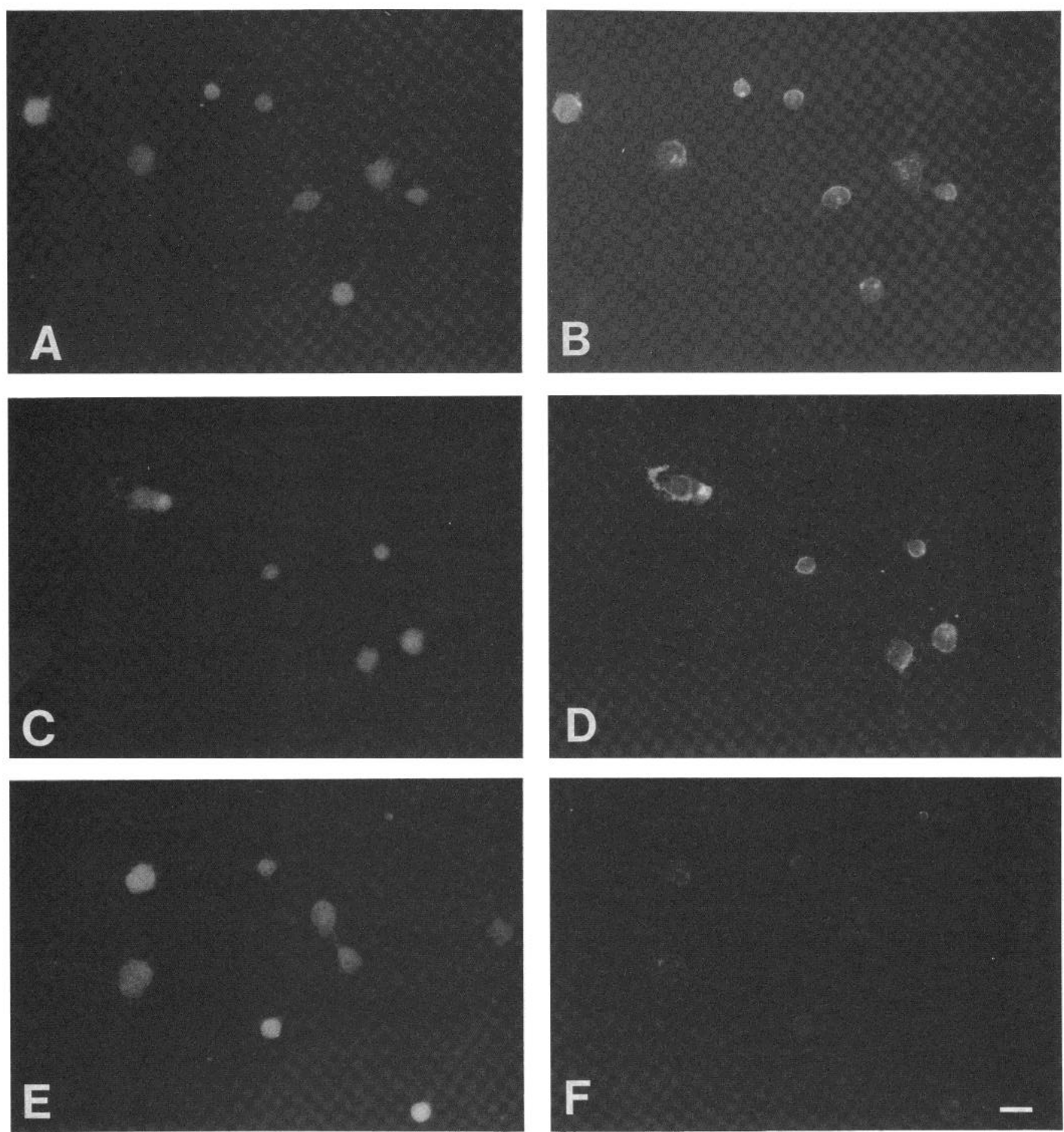

Figure 5. Distribution of Thy-1 antigen on ganglion cells. A ganglion cell-rich fraction from metrizamide gradient was obtained from 6-day-old rat pups. The cells were reacted first with a monoclonal antibody to Thy-1 and later were stained with $\mathrm{Rh}$ conjugated rabbit anti-mouse antibody. Ganglion cell-rich cultures were treated by the same protocol. When examined for TB $(A$ and $C)$ and Rh $(B$ and $D)$ fluorescence, the majority of TB-labeled cells in enriched fraction $(A$ and $B)$ or culture $(C$ and $D)$ showed Rh fluorescence. In controls, incubation with Thy-1 antibody was omitted. TB $(E)$ and Rh $(F)$ fluorescence in control (enriched fraction) is shown. Scale bar $=10 \mu \mathrm{m}$. 
nected by gap junctions (Stewart, 1978). However, such junctions between ganglion and amacrine cells have not been observed in the rat retina (Dubin, 1970).

The presence of $\mathrm{Na}^{+}$channels exclusively on TBlabeled cells further strengthens our contention that all TB-labeled cells are indeed ganglion cells. Moreover, the Thy-1 antigen, which has been localized to ganglion cells by other investigators (Beale and Osborne, 1982; C. Barnstable, personal communications), was found on virtually all TB-labeled cells.

During processing of culture plates, a significant number of fluorescent ganglion cells were seen in the washes. The decrease in ganglion cell number correlated with the appearance of large cells in the media that did not
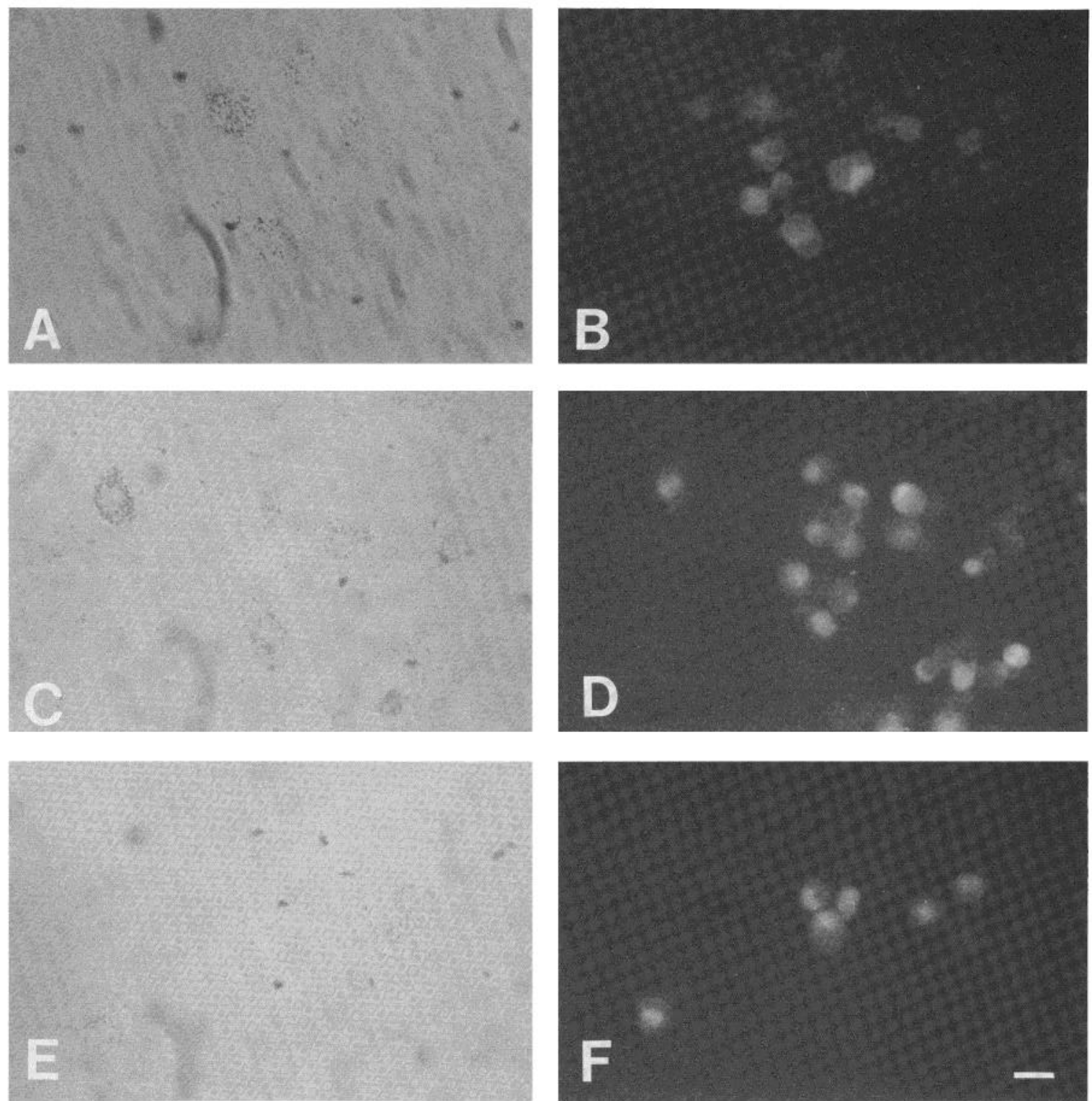

Figure 6. Uptake and accumulation of $\left[{ }^{3} \mathrm{H}\right]$ aspartate and $\left[{ }^{3} \mathrm{H}\right]$ glutamate by ganglion cells. Ganglion cell-rich cultures were washed and incubated with $0.5 \mu \mathrm{M} \mathrm{D}-\left[{ }^{3} \mathrm{H}\right]$ aspartate or $\mathrm{L}-\left[{ }^{3} \mathrm{H}\right]$ glutamate for $10 \mathrm{~min}$ at $37^{\circ} \mathrm{C}$. After fixation in $4 \%$ paraformaldehyde, the cells were processed for autoradiography. Light micrographs of $\mathrm{D}-\left[{ }^{3} \mathrm{H}\right]$ aspartate $(A)$ or $\left[{ }^{3} \mathrm{H}\right]$ glutamate $(C)$ and fluorescence micrographs of $\left[{ }^{3} \mathrm{H}\right]$ aspartate $(B)$ or $\left[{ }^{3} \mathrm{H}\right]$ glutamate $(D)$ uptake are presented. Note that only a few TB cells have a heavier grain distribution. Light $(E)$ and fluorescence $(F)$ micrographs of cultures incubated with $\left[{ }^{3} \mathrm{H}\right]$ aspartate in the presence of $100 \mu \mathrm{M}$ unlabeled D-aspartate are shown. The glutamate control was analogous. Scale bar $=10 \mu \mathrm{m}$. 

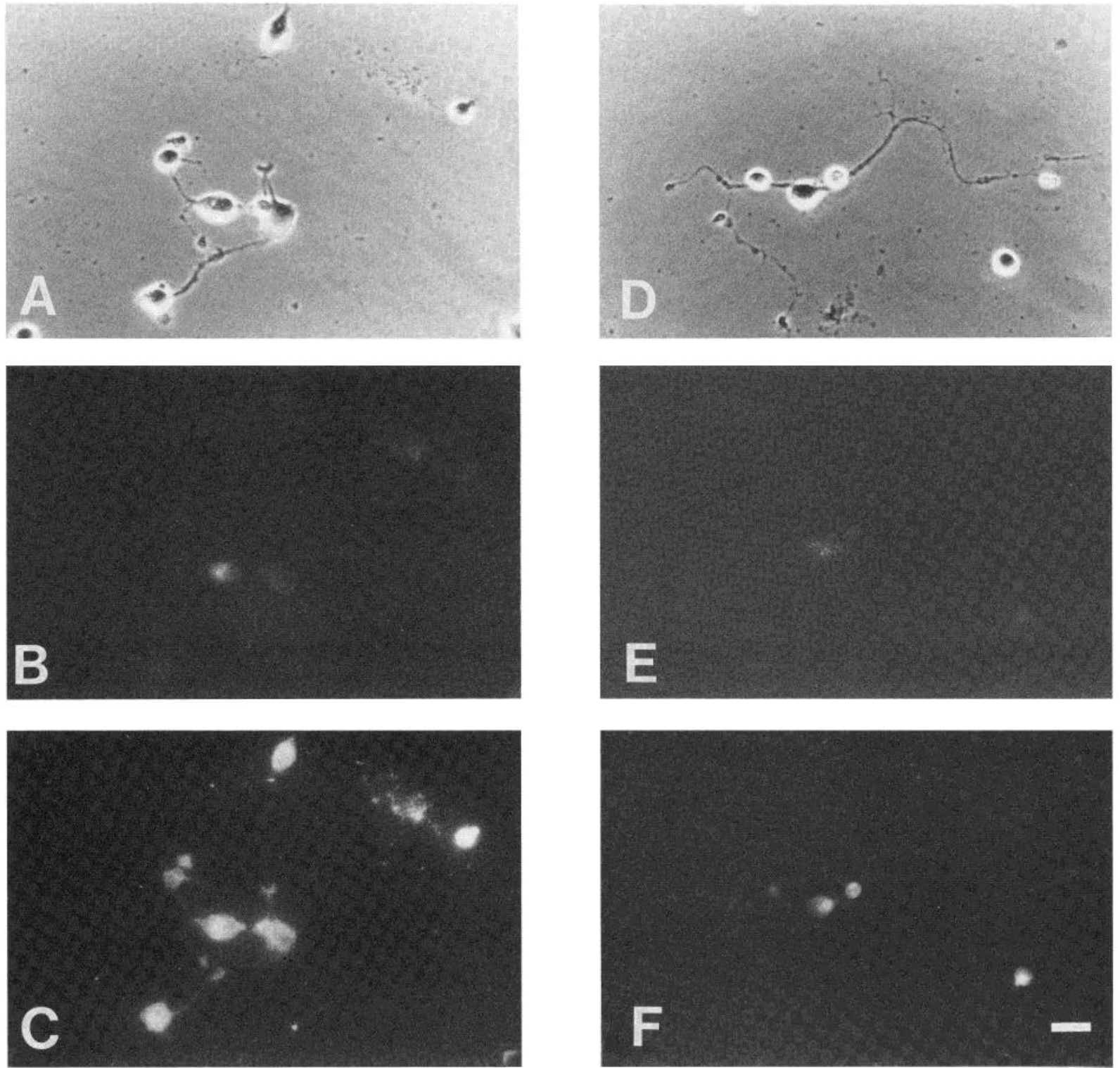

Figure 7. Wheat germ agglutinin binding to ganglion cells. Ganglion cell-rich cultures were incubated with $100 \mu \mathrm{g} / \mathrm{ml}$ of $\mathrm{Rh}$ conjugated wheat germ agglutinin in the absence (left) or presence (right) of $0.1 \mathrm{M} \mathrm{N}$-acetylglucosamine for 30 min at $37^{\circ} \mathrm{C}$. Cells were washed repeatedly and examined in situ with phase contrast optics $(A$ and $D)$, TB filter $(B$ and $E)$, and Rh filter $(C$ and F). Scale bar $=20 \mu \mathrm{m}$.

peratures, the cells clumped together to form large aggregates. Furthermore, yields were improved if centrifugation was performed in the absence of serum (Schnaar and Schaffner, 1981). A limitation of the enrichment procedure was that about 70 to $80 \%$ of the labeled cells in the enriched fractions were the large ganglion cells. Although it was possible to separate TB-labeled cells by a fluorescence-activated cell sorter, we have not been able to maintain them in vitro (unpublished results; see, however, McPheeters and Okun, 1980).

Our demonstration of the presence of Thy-1 antigen on TB-labeled cells is in agreement with the results of other investigators who have found that virtually all ganglion cell bodies carry this antigen on their surface (Beale and Osborne, 1982; C. Barnstable, personal communication). In the ganglion cell cultures, we found that about $20 \%$ of Thy-1-positive cells were devoid of TB
TABLE II

Lectin receptors on ganglion cells

\begin{tabular}{lcl}
\hline \multicolumn{1}{c}{ Lectin } & Binding & \multicolumn{1}{c}{ Competing Sugar } \\
\hline Wheat germ agglutinin & $+^{a}$ & $N$-Acetylglucosamine \\
Concanavalin A & + & Methyl- $\alpha$-mannoside \\
$\begin{array}{l}\text { Dichobolus biflorus agglu- } \\
\quad \text { tinin }\end{array}$ & + & $N$-Acetylgalactosamine \\
$\begin{array}{l}\text { Peanut agglutinin } \\
\text { Limulus polyphemus ag- }\end{array}$ & + & D-Galactose \\
$\quad$ glutinin & + & Sialic acid \\
$\begin{array}{l}\text { Ricinus communis agglu- } \\
\text { tinin I }\end{array}$ & $-{ }^{b}$ & NA $^{c}$ \\
$\begin{array}{l}\text { Soybean agglutinin } \\
\text { Lotus tetragono bolus }\end{array}$ & - & NA \\
Ulex & - & NA \\
\hline
\end{tabular}

${ }^{a}+$, binding above control level.

${ }^{b}-$, not detectable binding.

${ }^{c} \mathrm{NA}$, not applicable. 
fluorescence. This value is 3 -fold higher than that obtained with cells examined immediately after dissociation. The discrepancy may be due to leakage of dye from some cells in culture, rendering them difficult to be scored as TB positive.

Although the scorpion toxin-binding sites were restricted to TB-labeled cells, the presence of just a ring of silver grains around most of the labeled cells was puzzling. This localization appeared not to be an "edge" artifact of the autoradiographic technique for two reasons. First, no silver grains were found when ${ }^{125} \mathrm{I}$-scorpion toxin binding was carried out in the presence of excess unlabeled toxin. Second, few silver grains were found around nonfluorescent cells although adjoining neighbors were well labeled.

It may be pointed out here that the lack of $\mathrm{Na}^{+}$ channels on the nonfluorescent cells could be due to a slower rate of channel appearance on these cells. Resolution of these possibilities must await development of methods for maintaining ganglion cells in vitro for longer periods of time. In contrast to our results with retinal ganglion cells, neuroblastoma cells are uniformly labeled with scorpion toxin, and many spinal neurons in culture have a high density of sodium channels in one or more neurites (Catterall, 1981).

The validity of uptake as a criterion for transmitter localization has been repeatedly questioned, particularly in the case of the amino acid transmitters, aspartate and glutamate. Hence, our finding that a small fraction of ganglion cells were labeled with aspartate and glutamate cannot be construed as evidence that the labeled cells are indeed aspartatergic or glutamatergic neurons. However, it is noteworthy that in both the avian and the mammalian retina, D- $\left[{ }^{3} \mathrm{H}\right]$ aspartate uptake has been observed in only about 5 to $10 \%$ of cells in the ganglion cell layer (Beaudet et al., 1981; Cuenod et al., 1981; Ehinger, 1981), a value similar to that obtained in the present study.

Our ability to localize certain lectin receptors in situ by noninvasive methods suggests that it may be possible to study the localization and turnover of other receptors, such as the neurotransmitter receptors, on the ganglion cell surface. An obvious limitation of this approach is that, since considerable quenching of TB fluorescence occurs in aqueous medium, we may be restricted to examining receptor distribution on only the brightly labeled ganglion cells. Furthermore, only those receptors which are present at a high density or occur in clusters may be amenable for study. However, application of image intensification techniques may alleviate these problems (Kater and Hadley, 1982).

Neurochemical studies of ganglion cells are complicated by the anatomical separation of the soma and its synaptic terminals. The presence of displaced amacrine cells and glial cells in the ganglion cell layer further add to this problem. The availability of highly enriched cultures of identified ganglion cells should be of considerable utility in understanding the synaptic chemistry of retinal ganglion cells. Such preparations will also be useful in determining electrical properties of the ganglion cell membrane and the sensitivity of ganglion cells to putative amacrine cell neurotransmitters.

\section{References}

Beale, R., and N. N. Osborne (1982) Localization of the Thy-1 antigen to the surfaces of rat retinal ganglion cells. Neurochem. Int. 4: 587-595.

Beaudet, A., A. Burkhalter, J. -C. Reubi, and M. Cuenod (1981) Selective biochemical transport of ${ }^{3} \mathrm{H}$-D-aspartate in the pigeon retinotectal pathway. Neuroscience 6: 2021-2034.

Berger, S. J., M. L. McDaniel, J. G. Carter, and O. H. Lowry (1977) Distribution of four potential transmitter amino acids in monkey retina. J. Neurochem. 28: 159-163.

Catterall, W. A. (1977) Membrane potential dependent binding of scorpion toxin to the action potential sodium ionophore. Studies with a derivative prepared by lactoperoxidase-catalyzed iodination. J. Biol. Chem. 252: 8660-8668.

Catterall, W. A. (1980) Neurotoxins that act on voltage-sensitive sodium channels in excitable membranes. Annu. Rev. Pharmacol. Toxicol. 20: 15-43.

Catterall, W. A. (1981) Localization of sodium channels in cultured neural cells. J. Neurosci. 1: 777-783.

Cuenod, M., A. Beaudet, and V. Canzek (1981) Glutamatergic pathways in the pigeon and the rat brain. In Glutamate as a Neurotransmitter, G. Dichiara and G. L. Gessu, eds., pp. 5768, Raven Press, New York.

Dubin, M. W. (1970) The inner plexiform layer of the vertebrate retina. A quantitative and comparative electron microscopic analysis. J. Comp. Neurol. 140: 479-506.

Ehinger, B. (1981) $\left[{ }^{3} \mathrm{H}\right]-\mathrm{D}-$ Aspartate accumulation in the retina of pigeon, guinea pig, and rabbit. Exp. Eye Res. 33: 381-391.

Fonnum, F., and H. Henke (1979) Effect of retinal ablation on the pool of some amino acids in different layers of pigeon tectum. Experientia 35: 919-920.

Fukuda, Y. (1977) A three-group classification of rat retinal ganglion cells: Histological and physiological studies. Brain Res. 119: 327-334.

Giloh, H., and J. W. Sedat (1982) Fluorescence microscopy: Reduced photobleaching of rhodamine and fluorescence protein conjugates by $n$-propylgallate. Science $217: 1252-1255$.

Kater, S. B., and R. D. Hadley (1982) Video monitoring of neuronal plasticity. Trends Neurosci. 5: 80-82.

Kuypers, H. G. J. M. (1981) Procedure for retrograde double labeling with fluorescent substances. In Neuroanatomical Tract-Tracing Methods, L. Heimer and M. J. Robards, eds., pp. 299-303, Plenum Press, New York.

Lis, H., and N. Sharon (1973) The biochemistry of plant lectins (phytohemaglutinins). Annu. Rev. Biochem. 42: 541-574.

Masland, R. H., and U. C. Dräger (1980) Secondary labeling of retinal neurons by retrogradely transported dye. Soc. Neurosci. Abstr. 6: 212.

McCaffrey, C. A., M. R. Bennett, and B. Dreher (1982) The survival of neonatal rat ganglion cells in vitro is enhanced in the presence of appropriate parts of the brain. Exp. Brain Res. 48: 377-386.

McPheeters, M., and L. M. Okun (1980) Identification and isolation in vitro of presumptive motoneurons marked by retrograde transport of a new fluorescent tracer. Soc. Neurosci. Abstr. 6: 733.

Miller, R. F. (1979) The neuronal basis of ganglion cell receptive field organization and the physiology of amacrine cells. In The Neurosciences: Fourth Study Program, F. O. Schmidt and F. G. Worden, eds., pp. 227-245, MIT Press, Cambridge, MA.

Nicholson, G. L. (1976) Interaction of lectins with animal cell surfaces. Int. Rev. Cytol. 39: 89-190.

Nurcombe, V., and M. R. Bennett (1981) Embryonic chick retinal ganglion cells identified "in vitro." Their survival is dependent on a factor from the optic tectum. Exp. Brain Res. 44: 249-258. 
Oppenheimer, S. B. (1979) Interactions of lectins with embryonic cell surfaces. Curr. Top. Dev. Biol. 11: 1-16.

Peters, A., S. L. Palay, and H. deF. Webster (1976) The Fine Structure of the Nervous System: The Neurons and Supporting Cells, W. B. Saunders Co., Philadelphia.

Potts, R. A., B. Dreher, and M. R. Bennett (1982) The loss of ganglion cells in the developing retina of the rat. Dev. Brain Res. 3: 481-486.

Sarthy, P. V. (1982) The uptake of $\left[{ }^{3} \mathrm{H}\right] \gamma$-aminobutyric acid by isolated glial (Müller) cells from the mouse retina. J. Neurosci. Methods 5: 77-82.

Sarthy, P. V., and G. W. Balkema (1981) Retrograde labeling and dissociation of mouse retinal ganglion cells. Neurosci. Lett. 25: 205-208.

Sarthy, P. V., C. D. Bridges, F. L. Kretzer, and D. M. K. Lam (1981) Lectin receptors on cells isolated from the turtle retina. J. Comp. Neurol. 202: 561-569.

Schaffer, J. M., D. E. Schmeckel, P. M. Conn, and M. J. Brownstein (1980) A simple and rapid method to isolate rat retinal cells for biochemical analysis. Neuropeptides 1: 39 45 .

Schnaar, R. L., and A. E. Schaffner (1981) Separation of cell types from embryonic chicken and rat spinal cord: Charac- terization of motoneuron-enriched fractions. J. Neurosci. 1: 204-217.

Sheffield, J. B., D. Pressman, and M. Lynch (1980) Cells isolated from the embryonic neural retina differ in behavior in vitro and membrane structure. Science 209: 1043-1045.

Stewart, W. W. (1978) Functional connections between cells as revealed by dye-coupling with a highly fluorescent naphthalimide tracer. Cell 14: 741-759.

Varon, S., and M. Saier (1975) Culture techniques and glialneuronal interrelationships in vitro. Exp. Neurol. 48: 135162.

Vuaden, M. J., B. Marjaria, and A. C. I. Oraedu (1981) The localization and metabolism of glutamate, aspartate and GABA in the rat brain. Neurochem. Int. 1: 151-165.

Williams, A. F., A. W. Barclay, M. Latarte-Muirhead, and R. J. Morris (1976) Rat Thy-1 antigens from thymus and brain. Their tissue distribution, purification, and chemical composition. Cold Spring Harbor Symp. Quant. Biol. 41: 51-61.

Wolfensberger, M., V. Canzek, U. Amsler, and M. Cuenod (1981) In vivo release of aspartate and glutamate upon optic nerve stimulation in pigeon using mass fragmentography. Neurosci. Lett. 7: 29-33. 